\title{
Ukryte formy zadłużenia jednostek samorządu terytorialnego - próba oceny zjawiska
}

\section{Hidden Debt Forms of the Local Authorities - an Attempt of Assessment}

\begin{abstract}
Streszczenie. Artykuł porusza najistotniejsze kwestie związane z ukrywaniem zadłużenia przez jednostki samorządu terytorialnego w Polsce. Analizie zostały poddane rozmaite formy ukrywania zadłużenia, które wykorzystywane są przez jednostki samorządowe do dokapitalizowania swoich budżetów. Ukazano również obowiązujące na przestrzeni kilku minionych lat rozwiązania regulacyjne, które zostały wdrożone po to, by doprowadzić do ograniczenia nadmiernego rozrostu tego zjawiska. Całość omówionych zagadnień znajduje swoje dopełnienie w ostatniej części artykułu, w której autor dochodzi do konkluzji - wyrażając potrzebę uwzględnienia zadłużenia narosłego wskutek posługiwania się tymi formami w obowiązujące sprawozdawczości budżetowej.
\end{abstract}

Słowa kluczowe: jednostki samorządu terytorialnego; ukryte formy długu; granice zadłużenia. 


\begin{abstract}
The article presents some of the most important issues related to the hidden debt forms of the local authority in Poland. In particular, draws attention to the characteristic of different types of them. Additionally, this article discusses a significant provision of laws, which has provided by the Minister of Finance to elimination of debt limit evasion. Moreover, bearing in mind the above is should be noted that the necessity of consider the non-budgetary funds in the budget reporting.
\end{abstract}

Keywords: local authorities; hidden debt forms; debt limits.

\title{
1. Wprowadzenie
}

Problematyka zadłużania się jednostek samorządu terytorialnego (dalej: j.s.t.) zachowuje swoją aktualność niezmiennie od kilku lat, ukazując przy tym szereg zjawisk, które w okresie prosperity nie ujawniają się z takim natężeniem. W warunkach kryzysu gospodarczego ze szczególną wyrazistością dają o sobie znać nie tylko poważne trudności z utrzymaniem przez j.s.t. dopuszczalnych granic zadłużenia, ale też - co istotniejsze określonego rodzaju próby ich ominięcia ${ }^{1}$. Ogólnie mówiąc, tego typu zjawiska, będąc pochodną istniejących ograniczeń oraz indywidualnych możliwości finansowych poszczególnych wspólnot samorządowych, odgrywają współcześnie coraz większe znaczenie przy realizowaniu przez nie szeroko zakrojonych działań inwestycyjnych w infrastrukturę lokalną.

Sposobność do podejmowania przez j.s.t. naszkicowanych powyżej (utajonych) działań w zakresie operacji zadłużeniowych stwarza z jednej strony wąsko zarysowany katalog tytułów dłużnych, poza obrębem którego j.s.t. szukają remedium na obowiązujące limity, z drugiej zaś brak odzwierciedlenia zasygnalizowanych powyżej zjawisk w obowiązującej sprawozdawczości budżetowej. Jednocześnie pokusa sięgnięcia po ukryte formy długu jest tym większa, im wpływy z dotychczasowych źródeł dochodów ulegają postępującej erozji na skutek czynników niezależnych

1 Zob. M. Klupczyński, Wielka ucieczka przed wskaźnikiem, „Wspólnota” 2014, nr 8, s. 61-62. 
od samych j.s.t. ${ }^{2}$, a także w sytuacji wyraźnego podwyższenia kosztów pozyskania i obsługi zwrotnych źródeł finansowania ${ }^{3}$. Polskie j.s.t. ewidentnie na przestrzeni minionych kilku lat takim czynnikom podlegają. Od 2009 r. ulega systematycznemu pogorszeniu ich sytuacja finansowa, skłaniając skarbników j.s.t. do poszukiwania najbardziej optymalnych sposobów finansowania różnorodnych przedsięwzięć z pominięciem ustawowych restrykcji regulujących dług lokalny.

Celem niniejszego opracowania jest uporządkowanie stanu wiedzy na temat dostępnych form ukrywania długu wykorzystywanych przez j.s.t., a także ocena aktualnych rozwiązań regulacyjnych, które zostały wprowadzone po to, aby zahamować nadmierny rozrostu tego zjawiska.

\section{Formy ukrywania długu wykorzystywane przez jednostki samorządu terytorialnego}

\subsection{Rodzaje poszczególnych form ukrywania długu}

Kwestia odpowiedzialnego podejścia do poszczególnych form ukrywania długu, za pomocą których j.s.t. mogą inwestować w rozwój infrastruktury lokalnej, ma kapitalne znaczenie z punktu widzenia nie tylko zachowania bezpiecznych granic ich zadłużenia, lecz także zapewnienia tym jednostkom bieżącej płynności finansowej. Ustawodawca, mając świadomość doniosłości rysującego się tu problemu, związał j.s.t. ustawowymi regu-

2 Przykładem może być pozbawienie gmin znaczącej części wpływów z podatku od nieruchomości w wyniku zmiany definicji budowli sieciowych. Zmiana ta oznaczała dodatkowy zysk dla firm telekomunikacyjnych czy energetycznych, a dla mieszkańców zmniejszenie inwestycji gminnych - zob. R. Grobelny, Stanowisko Zwiq̨zu Miast Polskich $w$ sprawie stanu finansów miast na tle całego sektora finansów publicznych, „Samorząd Terytorialny” 2011, nr 4, s. 90.

3 I. Fąfara, Koszt pieniqdza dla samorzq̨du dziś i jutro, VII Samorządowe Forum Kapitału i Finansów, Warszawa, 6-7 października 2009 r., http://www.samorządoweforum.pl/ index.php?id=prezentacje (dostęp: 29.11.2014 r.); A. Kamiński, Finansowanie dłużne w jednostkach samorzqdu terytorialnego, Warszawa 2012, s. 125-126. 
łami, które zakładają w szczególności określoność źródeł środków finansowych angażowanych w wykonanie budżetu. Nie wyeliminowało to jednak wielu alternatywnych (pozabudżetowych) form pozyskiwania kapitału przez j.s.t., które znajdują obecnie zastosowanie ${ }^{4}$. Chodzi tu w szczególności o określone kategorie umów prawa cywilnego, które nie mają swego umiejscowienia w obowiązujących przepisach Kodeksu cywilnego ${ }^{5}$, ale także pewne specyficzne konstrukcje prawne, które nie zostały w nim zdefiniowane. Wydaje się za wskazane, dla rozjaśnienia dalszej części wywodu, choć w ogólnym zarysie ustalić ich zasadnicze cechy.

Cesja wierzytelności, zwana także przelewem, jest umową nazwaną, na podstawie której osoba trzecia (cesjonariusz) nabywa od dotychczasowego wierzyciela (cedenta) przysługującą mu wierzytelność ${ }^{6}$.

Faktoring stanowi umową nienazwaną, której istota sprowadza się do finansowania działalności przedsiębiorcy poprzez nabycie od niego wierzytelności przysługującej wobec jego kontrahentów ${ }^{7}$. Nabywca takiej wierzytelności, zwany faktorem, uzyskuje prowizję za wykup wierzytelności często przed terminem jej wymagalności. Jednocześnie jednak, bardzo często, zobligowany jest do świadczenia na rzecz dłużnika pewnych dodatkowych usług ${ }^{8}$. Natomiast zbywca, zwany cedentem, nie musi uciekać się do zaciągania drogiego kredytu bankowego, aby uzyskać przypływ środków pieniężnych.

Forfaiting jest umową nienazwaną, zgodnie z którą jedna ze stron zobowiązuje się do dostarczenia wierzytelności, zaś druga zobowiązuje się do zapłaty ceny już wcześniej uzgodnionej ${ }^{9}$. W rezultacie następuje tu dalsze odroczenie wykupu niewymagalnych wierzytelności, które są udo-

4 Zob. szerzej: P. Walczak, Zadłużenie jednostek samorzqdu terytorialnego oraz przestrzeganie ustawowych limitów zadłużenia i spłaty zobowiqzań w świetle wyników kontroli regionalnych izb obrachunkowych, „Finanse Komunalne” 2014, nr 9, s. 64-65.

5 Ustawa z dnia 23 kwietnia 1964 r. - Kodeks cywilny (tekst jedn. Dz.U. z 2014 r., poz. 121 ze zm.).

6 Z. Radwański, A. Olejniczak, Zobowiqzania - część ogólna, Warszawa 2010, s. 368.

K. Czajkowska-Matosiuk, Prawo gospodarcze i spółek, Warszawa 2011, s. 733.

8 G. Ostrzołek, Problemy finansowania inwestycji wierzytelnościami przez jednostki samorzqdu terytorialnego, „Finanse Komunalne” 2010, nr 3, s. 20.

9 K. Kruczalak, Factoring i jego gospodarcze zastosowanie, Warszawa 1997, s. 90. 
kumentowane w odpowiedni, akceptowany przez instytucję forfaitingową sposób. Ważną cechą tej umowy jest definitywny charakter przejścia wierzytelności na instytucję forfaitingową, wykluczając przez to ewentualność wystąpienia z regresem wobec cedenta w razie niewypłacalności dłużnika.

Kredyt handlowy, zwany również kupieckim lub towarowym, nie został zdefiniowany na gruncie prawnym, występuje zaś w teorii prawa gospodarczego i handlowego. Zgodnie z prezentowanym tam stanowiskiem jest on udzielany przez świadczącego usługę lub sprzedającego towar przyszłemu nabywcy w postaci odroczonego terminu płatności. Istota tego kredytu sprowadza się do zgody sprzedającego na otrzymanie zapłaty za wyświadczoną usługę lub dostarczony towar po upływie pierwotnie zakreślonego terminu $^{10}$.

Leasing jest umową nazwaną, której konstrukcja normatywna wynika z obustronnego stosunku obligacyjnego zawartego między finansującym a korzystającym z przedmiotu leasingu. Istotą tej umowy jest umożliwienie jednej ze stron korzystania z rzeczy w zamian za wynagrodzenie pieniężne, uiszczane ratalnie na rzecz finansującego, który zobowiązał się, w zakresie działalności swojego przedsiębiorstwa, nabyć rzecz od oznaczonego zbywcy i oddać ją do użytku korzystającemu ${ }^{11}$.

Partnerstwo publiczno-prywatne jest metodą współpracy władzy publicznej z partnerami prywatnymi. Polega ono na przekazaniu podmiotowi prywatnemu do realizacji zadań o charakterze publicznym ${ }^{12}$. Następuje to na podstawie umowy zawieranej pomiędzy jednostką publiczną a podmiotem prywatnym, dzięki której umiejętności oraz zasoby każdego z po-

10 W. Miemiec, Kategoria kredytu i pożyczki jako tytułów zaliczanych do państwowego długu publicznego $w$ ustawie o finansach publicznych $i$ w rozporzq̨dzeniu wydanym na jej podstawie, [w:] J. Szołno-Koguc, A. Pomorska (red.), Ekonomiczne i prawne uwarunkowania i bariery redukcji deficytu i długu publicznego, Warszawa 2011, s. 195.

11 M. Gutowski, Umowa leasingu, [w:] A. Koch, J. Niedbała (red.), Umowy w obrocie gospodarczym, Warszawa 2011, s. 127.

12 http://www.mg.gov.pl/Wspieranie+przedsiebiorczosci/Partnerstwo+publiczno+prywatne (dostęp: 29.11.2014 r.). 
szczególnych sektorów wykorzystywane są przy jednoczesnym dostarczaniu usług odbiorcom i udostępnianiu obiektów użyteczności publicznej ${ }^{13}$.

Spółka prawa handlowego jest alternatywnym wobec umowy cywilnej sposobem alokacji zasobów, polegającym na utworzeniu przez j.s.t. określonego typu jednostki organizacyjnej ${ }^{14}$, na którą można przesunąć ciężar zadłużenia. Następuje to poprzez finansowanie wydatków inwestycyjnych nie bezpośrednio z budżetu danej j.s.t., ale za pośrednictwem utworzonej spółki, której udziałowcem bądź akcjonariuszem jest samorząd ${ }^{15}$.

Komunalna spółka specjalnego przeznaczenia (dalej: k.s.s.p.) jest formułą długoterminowego finansowania inwestycji samorządowych, która polega na zawarciu specjalnej umowy między j.s.t. a instytucją finansową, na mocy której jednostka samorządowa nabywa w oznaczonym terminie określoną liczbę udziałów po uprzednim dokapitalizowaniu k.s.s.p. w drodze wkładu pieniężnego w wysokości równej planowanej inwestycji. Pośrednikiem zaś przy dokonywaniu tej transakcji jest instytucja finansowa, która w momencie nabycia przez j.s.t. udziałów w k.s.s.p. dokonuje ich umorzenia, otrzymując wynagrodzenie liczone jako koszt pieniądza w czasie z tytułu świadczonej usługi ${ }^{16}$.

Jak wynika z pobieżnej analizy powyżej omówionych form zadłużenia j.s.t., wszystkie z nich charakteryzują się odroczonym w czasie terminem zapadalności długu. W następstwie czego dochodzi do jego ukrycia. Jednocześnie pozwalają w relatywnie szybki i odformalizowany sposób uzyskać kapitał inwestycyjny, nie powiększając przy tym „oficjalnego” wskaźnika zadłużenia budżetu danej j.s.t. Stąd też wspomniane formy zadłużania się dla większości jednostek samorządowych mogą okazać się

13 The National Council for Public-Private Partnerships, http://www.ncppp.org/ about/overview-mission (dostęp: 29.11.2014); R. Ślusarczyk, Rosnq̨ce zadłużenie gmin a partnerstwo publiczno-prywatne, „Finanse Komunalne” 2013, nr 9, s. 51.

Katalog określonych typów spółek prawa handlowego, które mogą utworzyć j.s.t. został określony w art. 9 ustawy z dnia 20 grudnia 1996 r. o gospodarce komunalnej (tekst jedn. Dz.U. z 2011 r. Nr 45, poz. 236).

15 A. Babczuk, Zadłużenie spółek komunalnych w Polce. Próba oceny skali i zróżnicowania regionalnego, „Finanse Komunalne” 2012, nr 9, s. 16.

16 G. Piecek, Analiza wybranych form pozabudżetowego finansowania inwestycji infrastrukturalnych przez jednostki samorzqdu terytorialnego, „Finanse Komunalne” 2010, nr 1-2, s. 134-135. 
niezwykle atrakcyjnym i pociągającym rozwiązaniem, które może istotnie (choć nie bezpośrednio) rzutować na ich przyszłą sytuację finansową.

\subsection{Deeskalacja zjawiska ukrywania długu}

Zjawisko sięgania przez j.s.t. do rozmaitych pozabudżetowych form finansowania przedsięwzięć inwestycyjnych nie przeszło bez echa na kilku zazębiających się płaszczyznach. Z jednej bowiem strony można było obserwować stricte naukowe dociekania nad istotą i skutkami rzeczonego fenomenem, które w swej wymowie nie niosły zbyt pokrzepiających treści, z drugiej zaś nie obyło się bez konkretnych, acz nieoczekiwanych zabiegów legislacyjnych służących ograniczeniu skali przyrostu tej kategorii długu. Jedną z decyzji rządu służącą temu celowi było wydanie przez Ministra Finansów rozporządzenia w sprawie szczegółowego sposobu klasyfikacji tytułów dłużnych zaliczanych do państwowego długu publicznego, w tym długu Skarbu Państwa ${ }^{17}$. Rozporządzenie wydane zostało w oparciu o specjalnie w tym celu zmieniony art. 72 ust. 2 ustawy o finansach publicznych ${ }^{18}$, który w wersji sprzed nowelizacji zawierał tylko delegację ustawową, na mocy której Minister Finansów miał określić „w drodze rozporządzenia, szczegółowy sposób klasyfikacji tytułów dłużnych zaliczanych do państwowego długu publicznego”. Natomiast po wprowadzeniu nowelizacji dodano do treści przepisu wyrażenie „w tym rodzaje zobowiązań zaliczanych do tytułów dłużnych”"19. Nastąpiło wobec tego rozszerzenie upoważnienia do ustalania szczegółowego sposobu klasyfikacji tytułów dłużnych o dalsze ich rodzaje ${ }^{20}$. W ten sposób poszerzo-

Rozporządzenie Ministra Finansów z dnia 23 grudnia 2010 r. (Dz.U. Nr 252, poz. 1692).

Ustawa z dnia 27 sierpnia 2009 r. (tekst jedn. Dz.U. z 2013 r., poz. 885 ze zm.), dalej: u.f.p.

Zob. art. 1 pkt 5 ustawy z dnia 16 grudnia 2010 r. o zmianie ustawy o finansach publicznych oraz niektórych innych ustaw (Dz.U. Nr 257, poz. 1726).

20 I. Czaja-Hliniak, Nieprzestrzegania ustawy o finansach publicznych a dług publiczny jednostek samorzqdu terytorialnego, „Państwo i Prawo” 2011, nr 6, s. 45-46. 
no zakres klasycznych tytułów dłużnych, takich jak kredyty, pożyczki czy emisja papierów wartościowych o ${ }^{21}$ :

1. umowy o partnerstwie publiczno-prywatnym, które mają wpływ na poziom długu publicznego;

2. papiery dłużne, których zbywalność jest ograniczona;

3. umowy sprzedaży, których cena jest płatna w ratach;

4. umowy leasingu zawarte z producentem lub finansującym, w których ryzyko i korzyści z tytułu własności są przeniesione na korzystającego z rzeczy;

5. umowy nienazwane o terminie zapłaty dłuższym niż rok, związane z finansowaniem usług, dostaw, robót budowlanych, które wywołują skutki ekonomiczne podobne do umowy pożyczki lub kredytu.

Prezentowane rozwiązanie spotkało się ze zdecydowaną krytyką w zarówno teorii, jak i praktyce finansów sektora samorządowego ${ }^{22}$. W szczególności za niezwykle kontrowersyjne uznano utożsamienie z kategorią kredytu i pożyczki „umowy (...), które wywołują skutki ekonomiczne podobne do umowy pożyczki lub kredytu”²3. Posłużenie się bowiem tego rodzaju konstrukcją normatywną sprawiło, że podstawowa kategoria tytułów dłużnych stypizowana w art. 72 ust. 1 pkt 4 u.f.p., której zaliczenie do państwowego długu publicznego ograniczone było warunkiem wymagalności, została tego warunku pozbawiona. W ten sposób ograniczona została możliwość stosowania art. 72 ust. 1 pkt 4 u.f.p. w pełnym zakresie jego regulacji ${ }^{24}$. Problem ten został dostrzeżony przez niektórych przedstawicieli doktryny, którzy sformułowali nawet zarzut

21 K. Marchewka-Bartkowiak, M. Korolewska, Zadłużenie miast na prawach powiatu i województw w świetle badań ankietowych, „Analizy BAS” 2011, nr 13(57), s 8.

22 M. Kulesza, M. Bitner, Nowa definicja państwowego długu publicznego? Problemy zwiq̨zane z interpretacja przepisów rozporzq̨dzenia Ministra Finansów z 23.12.2010 r. w sprawie szczegółowego sposobu klasyfikacji tytułów dłużnych zaliczanych do państwowego długu publicznego, w tym Skarbu Państwa, „Samorząd Terytorialny” 2010, nr 11, s. 29; R. Grobelny, Stanowisko Zwiq̨zku Miast Polskich..., s. 89.

23 Zob. par. 3 pkt 2 rozporządzenia Ministra Finansów z dnia 23 grudnia 2010 r. (Dz.U. Nr 252, poz. 1692).

24 M. Mazurkiewicz, Problem zgodności z Konstytucja art. 72 ust 1 i 2 ustawy o finansach publicznych $w$ zw. z par 3 jej rozporzq̨dzenia wykonawczego - zagadnienia dyskusyjne, „Finanse Komunalne” 2011, nr 4, s. 8; W. Miemiec, Kategoria kredytu i pożyczki..., s. 193. 
sprzeczności powyższych unormowań z ustawą zasadniczą ${ }^{25}$ Z drugiej jednak strony mimo licznych „uchybień legislacyjnych”, jakie uwidoczniły się w treści cytowanego już rozporządzenia Ministra Finansów ${ }^{26}$, okazało się ono być niezwykle skutecznym instrumentem redukcji dotychczasowego poziomu zadłużenia j.s.t. Analiza skutków jego wprowadzenia dowiodła, iż ustanowienie nowych zasad zadłużania się spowodowało zauważalny spadek tempa wzrostu poziomu długu j.s.t. ${ }^{27}$. Rzecz jasna, nie obyło się to bez ograniczenia pewnej swobody, z jakiej do tej pory korzystały jednostki samorządowe przy poszukiwaniu alternatywnych dróg pozyskiwania kapitału ${ }^{28}$, niemniej zasadniczy cel jaki został postawiony przed tym aktem normatywnym został spełniony - ograniczenie dalszego przyrostu zadłużenia j.s.t..

\section{Konkluzje}

Podsumowując, należy stwierdzić, że nadal niedocenionym problemem pozostaje kwestia nadużywania ukrytych (pozabudżetowych) form finansowania inwestycji przez jednostki samorządu terytorialnego. Obowiązujące regulacje dotyczące zadłużenia zostały ukształtowane w ten sposób, iż nie obejmują wszystkich zaciąganych przez j.s.t. zobowiązań, które w ostatecznym rozrachunku powiększają ich dług. W efekcie rzeczywisty poziom zadłużenia całego podsektora samorządowego jest dużo wyższy od odzwierciedlających go oficjalnych informacji. Dlatego też tak ważnym i naglącym staje się bardziej kompleksowe i zarazem transparentne uregulowanie tej kwestii, która przecież niesie ze sobą niezwykle poważne implikacje praktyczne dla wysokości zadłużenia samorządów w świetle obowiązujących limitów. Wprawdzie za trafny należy uznać obrany do-

\footnotetext{
M. Mazurkiewicz, Problem zgodności z Konstytucjq..., s. 8.

26 Warto nadmienić, że wskazane zasady kalkulowania poziomu zadłużenia j.s.t., wprowadzone na mocy rozporządzenia Ministra Finansów z dnia 23 grudnia 2010 r., zostały zastąpione rozporządzeniem Ministra Finansów z dnia 28 grudnia 2011 r. (Dz.U. Nr 298, poz. 1767), które poza drobnymi legislacyjnymi poprawkami nie zostało poddane większym zmianom, zachowując sporny par. 3 pkt $2 \mathrm{w}$ dotychczasowym brzemieniu.

27 R. Ślusarski, Rosnqce zadłużenie gmin..., s. 50.

28 Zob. szerzej: R. Grobelny, Stanowisko Zwiq̨zu Miast Polskich..., s. 89.
} 
tychczas przez Ministra Finansów „kurs” bardziej restrykcyjnych działań legislacyjnych zmierzających ku deeskalacji tego zjawiska. Doprowadzając w ten sposób na przestrzeni paru ostatnich lat do znacznego zahamowania tempa przyrostu poziomu długu j.s.t. ${ }^{29}$ Niemniej dla autora niniejszej pracy nie jest to rozwiązanie całkowicie satysfakcjonujące. Przede wszystkim nie uwzględnia tak nadużywanej powszechnie przez wspólnoty samorządowe pozabudżetowej formy ukrywania długu, jaką jest spółka komunalna. W świetle dokonanej przez autora oceny skali tego zjawiska okazało się, iż niektóre samorządy tworzą wręcz specjalne spółki tylko po to, aby „uwolnić” się od krępujących je rygorów ustawowego poziomu zadłużenia $^{30}$. Czy zatem nie wydaje się za wskazane zaprzestanie dalszego tolerowania tego procederu, którego zresztą sam stopień wyrafinowania w ucieczce od długu - zakrawa na absurd? Co więcej, mechanizm ten jest o tyle potencjalnie dysfunkcyjny dla stabilności finansów komunalnych, że stwarza pewną iluzję relatywnie dobrej sytuacji ekonomiczno-finansowej panującej w danej jednostce przy faktycznym, nierzadko sporym obciążeniu jej, długami samorządowych spółek prawa handlowego. Należy więc za w pełni uzasadniony wysunąć postulat de lege ferenda objęcia tych podmiotów obowiązkiem sprawozdawczym, pozwalającym w zakresie pełniejszym, niż to miało miejsce dotychczas, oddać rzeczywisty stan zadłużenia wspólnot samorządowych.

\section{Bibliografia:}

Babczuk A., Zadłużenie spółek komunalnych w Polsce. Próba oceny skali i zróżnicowania regionalnego, „Finanse Komunalne” 2012, nr 9, s. 5-16.

Borodo A., Głos w sprawie zakresu i kształtu długu oraz deficytu jednostek samorzq̨du terytorialnego, „Finanse Komunalne” 2012, nr 1-2, s. 52-57.

29 Zob. R. Ślusarczyk, Rosnqce zadłużenie gmin..., s. 50-51.

30 Zob. P. Dobrowolski, Kryzys zadłużenia uderzy w samorzq̨y, „Wspólnota” 2011, nr 5, s. 11; A. Borodo, Głos w sprawie zakresu i kształtu długu oraz deficytu jednostek samorzqdu terytorialnego, „Finanse Komunalne” 2012, nr 1-2, s. 55; M. Klupczyński, W jakich długach tonq samorzqdy, „Wspólnota” 2014, nr 18, s. 55; P. Swianiewicz, J. Łukomska, Kto żyje na kredyt, „Wspólnota” 2013, nr 19, s. 52; P. Swianiewicz, J. Łukomska, Miasta nadal w długach, gminy i powiaty oszczędzajq, „Wspólnota” 2014, nr 19, s. 45-46. 
Czaja-Hliniak I., Nieprzestrzegania ustawy o finansach publicznych a dług publiczny jednostek samorzq̨du terytorialnego, „Państwo i Prawo” 2011, nr 6, s. 44-50.

Czajkowska-Matosiuk K., Prawo gospodarcze i spółek, C.H. Beck, Warszawa 2011.

Dobrowolski P., Kryzys zadłużenia uderzy w samorzq̨dy, „Wspólnota” 2011, nr 5, s. $10-11$.

Grobelny R., Stanowisko Zwiq̨zku Miast Polskich w sprawie stanu finansów miast na tle całego sektora finansów publicznych, „Samorząd Terytorialny” 2011, nr 4, 88-90.

Gutowski M., Umowa leasingu, [w:] A. Koch, J. Niedbała (red.), Umowy w obrocie gospodarczym, Wolters Kluwer, Warszawa 2011.

Kamiński A., Finansowanie dłużne w jednostkach samorzq̨du terytorialnego, Wolters Kluwer, Warszawa 2012.

Klupczyński M., Wielka ucieczka przed wskaźnikiem, „Wspólnota” 2014, nr 8, s. 60-62.

Klupczyński M., W jakich długach tonq samorzq̨dy, „Wspólnota” 2014, nr 18, s. 54-56.

Kruczalak K., Factoring i jego gospodarcze zastosowanie, Wydawnictwa Prawnicze PWN, Warszawa 1997.

Kulesza M., Bitner M., Nowa definicja państwowego długu publicznego? Problemy zwiqzzane z interpretacjq przepisów rozporzq̨dzenia Ministra Finansów z 23.12.2010 r. w sprawie szczegółowego sposobu klasyfikacji tytułów dłużnych zaliczanych do państwowego długu publicznego, w tym Skarbu Państwa, „Samorząd Terytorialny” 2010, nr 11, s. 15-30.

Marchewka-Bartkowiak K., Korolewska M., Zadłużenie miast na prawach powiatu i województw w świetle badań ankietowych, „Analizy BAS” 2011, nr 13 (57), s. 1-10.

Mazurkiewicz M., Problem zgodności z Konstytucją art. 72 ust 1 i 2 ustawy o finansach publicznych $w \mathrm{zw}$. z par 3 jej rozporzqdzenia wykonawczego zagadnienia dyskusyjne, „Finanse Komunalne” 2011, nr 4, s. 5-13.

Miemiec W., Kategoria kredytu i pożyczki jako tytułów zaliczanych do państwowego długu publicznego $w$ ustawie o finansach publicznych $i$ w rozporzqdzeniu wydanym na jej podstawie, [w:] Szołno-Koguc J., Pomorska A. (red.), Ekonomiczne i prawne uwarunkowania i bariery redukcji deficytu i długu publicznego, Wolters Kluwer, Warszawa 2011.

Ostrzołek G., Problemy finansowania inwestycji wierzytelnościami przez jednostki samorzq̨du terytorialnego, „Finanse Komunalne” 2010, nr 3, s. 18-33. 
Piecek G., Analiza wybranych form pozabudżetowego finansowania inwestycji infrastrukturalnych przez jednostki samorzqdu terytorialnego, „Finanse Komunalne” 2010, nr 1-2, s. 130-136.

Radwański Z., Olejniczak A., Zobowiq̨zania - część ogólna, C.H. Beck, Warszawa 2010.

Swianiewicz P., Łukomska J., Kto żyje na kredyt, „Wspólnota” 2013, nr 19, s. 51-54.

Swianiewicz P., Łukomska J., Miasta nadal w długach, gminy i powiaty oszczędzajq, „Wspólnota” 2014, nr 19, s. 42-51.

Ślusarczyk R., Rosnqce zadłużenie gmin a partnerstwo publiczno-prywatne, „Finanse Komunalne” 2013, nr 9, s. 46-55.

Walczak P., Zadłużenie jednostek samorzqdu terytorialnego oraz przestrzeganie ustawowych limitów zadłużenia i spłaty zobowiqzań w świetle wyników kontroli regionalnych izb obrachunkowych, „Finanse Komunalne” 2014, nr 9, s. $55-71$. 